\title{
非定常弾性応答時における応答低減係数の評価 \\ EVALUATION OF RESPONSE REDUCTION FACTOR IN NON-STATIONARY ELASTIC RESPONSE
}

\author{
大塚悠里 ${ }^{* 1}$, 朱 盈 ${ }^{* 2}$, 伊藤 美 瑛*3, 大出大輔 ${ }^{* 4}$, 平石久廣 ${ }^{* 5}$ \\ Yuri OTSUKA, Ying ZHU, Miei ITO, \\ Daisuke ODE and Hisahiro HIRAISHI
}

\begin{abstract}
This paper presents the revised response reduction factor with higher accuracy, which is modified from the past proposal. In the modification, two phenomena are considered. One is the influence of the asymmetry of response of one cycle just before the maximum response on the calculation of the equivalent damping factor. The other is the influence of the change of the period due to the damping. The paper also proposes simplified formula for the response reduction factor. Finally, the consistency of the modified formula and the simplified formula with the time history analytical results is investigated, which proves the excellent compatibility.
\end{abstract}

\section{Keywords : Response reduction factor, Non-stationary response, Elastic single-mass system, One cycle at the maximum response, Projecting ratio, Absorbed energy by damping factor 応答低減係数, 非定常応答, 弾性一質点系, 最大応答時の 1 サイクル, 突出比, 減衰による吸収エネルギー}

\section{1. はじめに}

減衰による応答低減係数は、地震時における構造物の応答を簡易 に予測することができ、建物の耐震性能を効率よく把握できること から限界耐力計算など、耐震設計に関寸る多くの規準に採用されて いる。また、構造特性の位置づけなど耐震に係る研究にも多用され ている。このため、古くから多くの研究者により研究が進められて きた。既往の応答低減係数の代表的なものとしては建築研究所式 ${ }^{1)}$ 、 笠井式 2)、秋山式 3)等があげられる。しかしながら、これらの応答低 減係数は統計的な計算により求められた回帰式であり、理論的な背 景に乏しく、入力地震動や建物の復元力特性により提案式と解析值 との間にばらつきや隔離がみられ検討の余地がある ${ }^{2), 3) 。 ~}$

また、非定常応答の理論的な考察としては、地震時の非定常性を 考慮しつつ、主要動区間を定常ランダムと見做すことにより疑似速 度スペクトルとエネルギースペクトルの関係式を導出した岡野等の 研究 ${ }^{4)}$ があ゙られる。しかしながら、減衰定数が 0.05 より大きい範 囲は適応外であり、また、応答低減係数は提案されていない。

一方、著者等は弾性、弾塑性一質点系が定常応答する場合におけ る最大応答時の 1 サイクル分の吸収エネルギーの関係に着目し、入 カエネルギーと減衰による吸収エネルギー及び履歴による吸収エネ ルギーとの関係から、定常応答時における弾性モデル、武田モデル、 バイリニアモデル、武田スリップモデルの応答低減係数の理論式を
誘導し、それらが時刻歴応答解析結果と極めて良く整合することを 示している5)。

また、著者等は非定常応答時における弾性一質点系の応答低減係 数についてもエネルギーの釣合に基づき理論的に誘導している ${ }^{6)}$ 具体的には、最大応答直前の 1 サイクルに着目し、最大応答直前の ピーク值から最大応答に至るまでの歪エネルギーの増分、定常ルー プを描く時の減衰による吸収エネルギー及び最大応答と最大応答直 前のピーク值の比率(以下: 突出比)を用い、非定常応答時における応 答低減係数の評価式を誘導した。さらに、減衰による吸収エネルギ 一を定常応答時から非定常応答時に修正する係数(以下: 修正係数) を算出し、その值が突出比と近似できることから、応答低減係数の 略算式((9)式)を提案している。

しかしながら、提案された応答低減係数の略算解は応答解析結果 の下限值を描き、また、減衰定数が増大寸るにつれて応答解析結果 の平均值との差異が大きくなる傾向を示した。さらに、応答解析結 果より得られた応答低減係数は建物周期によってばらつきがみられ た。

このため、本論文では文献 6)を基に、減衰による吸収エネルギー に応答の非対称性を加味した修正係数と減衰による周期の变動が応 答低減係数に及ぼす影響を考慮しうる補正係数を用いた応答低減係 数の修正式を提案する。また、建物周期ごとの修正係数と突出比を
*1 明治大学大学院 博士後期課程 $\cdot$ 大学院生 日本学術振興会特別研究員 DC1 - 修士 (工学)

*2 (株)フジタ技術センター 修士 (工学)

*3 明治大学大学院 博士前期課程·大学院生

*4 (株)大林組技術研究所

明治大学大学院 博士後期課程 $\cdot$ 大学院生 · 修士 (工学)

*5 明治大学理工学部建築学科 教授. 工博 (国立研究開発法人建築研究所 客員研究員)
Grad. Student, Graduate School of Science and Technology, Meiji Univ. Research Fellow of Japan Society for the Promotion of Science, M.Eng. Technology Development Division, Fujita Corporation, M.Eng. Grad. Student, Graduate School of Science and Technology, Meiji Univ. Technical Research Institute, Obayashi Corporation

Grad. Student, Graduate School of Science and Technology, Meiji Univ., M.Eng. Prof., Dept. of Architecture, School of Science and Technology, Meiji Univ., Dr.Eng. (Visiting Research Fellow, Building Research Institute) 
用いた具体的な応答低減係数を算出し、応答解析結果との比較から その整合性を検証する。さらに、応答低減係数の修正式を基に応答 低減係数の簡易式を誘導し、応答解析結果及び既往の提案式との比 較からその適合性を示す。

\section{2. 文献 ${ }^{6)}$ の応答低減係数の提案式とその検討課題}

本章では、本論文の基本となる文献 6)で誘導した非定常応答時に おける弾性一質点系の 1 サイクル分のエネルギーの関係式、応答低 減係数の理論式並びに文献 6 の略算式とその検討課題を示す。

\subsection{1 サイクル分のエネルギーの釣合式}

Fig.1 に弾性一質点系が非定常応答をする時の応答变位 $\mathrm{y}$ と時刻 $\mathrm{t}$ の関係を示す。また、非定常応答状態における復元力特性(Fig.2)を、 減衰力と剛性 $\mathrm{k}$ を有する弾性系で表した場合を Fig. 3 及び Fig.4 に 示す。Fig.2 の減衰による吸収エネルギー ${ }_{\mathrm{e}} \mathrm{E}_{\mathrm{d}}$ は、Fig.3 の減衰力 $C \dot{y}$ の面積による仕事量で与えられる。

一方、弾性一質点系の最大応答時における 1 サイクル分のエネル ギーの釣合式は(1)式で得られ、(2)式で表せる。

$$
\begin{gathered}
\int_{t_{1}}^{t_{2}} M \ddot{y} \dot{y} d t+\int_{t_{1}}^{t_{2}} C \dot{y}^{2} d t+\int_{t_{1}}^{t_{2}} k y \dot{y} d t=-\int_{t_{1}}^{t_{2}} M \ddot{z} \dot{y} d t \\
e^{E_{d}+{ }_{e} E_{\Delta}=E}
\end{gathered}
$$

$$
\begin{array}{cc}
M \ddot{y}: \text { 慣性力 } & C \dot{y}: \text { 減衰力 } \\
k y: \text { 復元力 } & M \ddot{z}: \text { 地震力 } \\
{ }^{E} E_{d}: 1 \text { サイクル分の減衰による吸収エネルギー } \\
{ }_{e} E_{\Delta}: 1 \text { サイクル分の弾性歪エネルギーの増分 } \\
E: 1 \text { サイクル分の地動による入力エネルギー }
\end{array}
$$

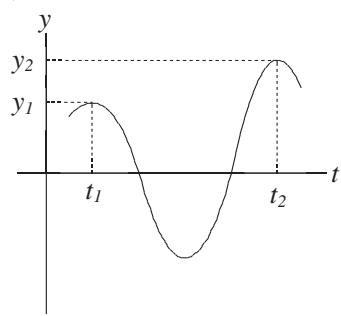

Fig.1 Time history of displacement for one cycle before the maximum response

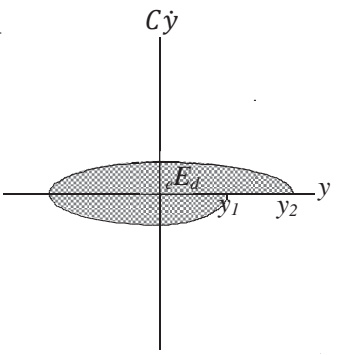

Fig.3 Damping force and absorbed energy

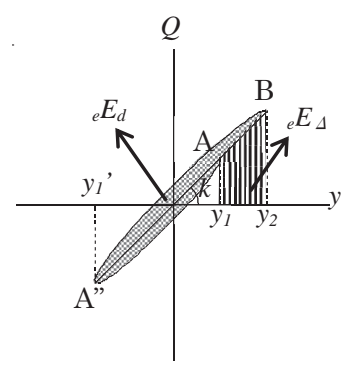

Fig.2 Hysteresis characteristics and absorbed energy

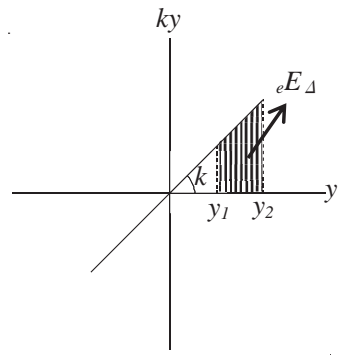

Fig.4 Elasticity

\section{2. 応答低減係数の理論式}

文献 6)では、減衰定数 h による応答の違いを Fig.5 のように仮定 し、応答低減係数 $F_{h}$ を(3)式で与えている。また、応答低減係数の一 般式は(2)式から、(4)式で与えられる。

$$
\begin{gathered}
\frac{y_{h}}{y_{0}}=\frac{y_{h \max }}{y_{0 \max }}=F_{h} \\
F_{h}=\frac{{ }_{e} E_{d 0}+{ }_{e} E_{\Delta 0}}{\frac{h}{h_{0}}{ }_{e} E_{d 0}+{ }_{e} E_{\Delta 0}}
\end{gathered}
$$

$$
\begin{aligned}
& h, h_{0}: \text { 減衰定数 } \\
& y_{0}: h=h_{0} \text { の時の応答変位 } \\
& y_{h}: h=h \text { の時の応答変位 } \\
& y_{0 \max }: h=h_{0} \text { の時の最大応答変位 }\left[y_{2}\left(h=h_{0}\right)\right] \\
& y_{h \max }: h=h \text { の時の最大応答変位 }\left[y_{2}(h=h)\right] \\
& { }_{e} E_{d 0}: h=h_{0} \text { の時の減衰による吸収エネルギー } \\
& { }_{e} E_{\Delta 0}: h=h_{0} \text { の時の弾性歪エネルギーの増分 }
\end{aligned}
$$

また文献 6)では、減衰定数 $h=h_{0}$ の時の減衰による吸収エネルギ $-{ }_{\mathrm{e}} \mathrm{E}_{\mathrm{d} 0}$ を歪エネルギーの面積 $\mathrm{e}_{\mathrm{e}} \mathrm{E}_{\mathrm{e}}$ (三角形 $\mathrm{OAC}$ )を用いて、Fig.6 のよ うな正負対称の減衰による吸収エネルギーの時に成立する(5)式で 表している。

$$
e^{E_{d 0}}=4 \pi h_{0} \cdot e^{E_{e 0}}
$$

非定常応答時の応答低減係数は、減衰定数 $h=h_{0}$ の時の応答変位 $\mathrm{y}_{1}$ と $\mathrm{y}_{2}$ の比率(突出比 $\gamma_{0}((6)$ 式))並びに、減衰による吸収エネルギー に(7)式の修正係数 $\beta_{0}$ を用い、(8)式で与えている。

$$
\begin{gathered}
\gamma_{0}=\frac{y_{2}\left(h=h_{0}\right)}{y_{1}\left(h=h_{0}\right)} \\
\beta_{0}=\frac{\text { 楕円 } \mathrm{AA}^{\prime} \mathrm{BA} \text { の面積 }\left(h=h_{0}\right)}{\text { 楕円AA'A の面積 }\left(h=h_{0}\right)} \\
F_{h}=\frac{\beta_{0} \cdot 4 \pi h_{0}+\left(\gamma_{0}^{2}-1\right)}{\beta_{0} \cdot 4 \pi h+\left(\gamma_{0}^{2}-1\right)}
\end{gathered}
$$

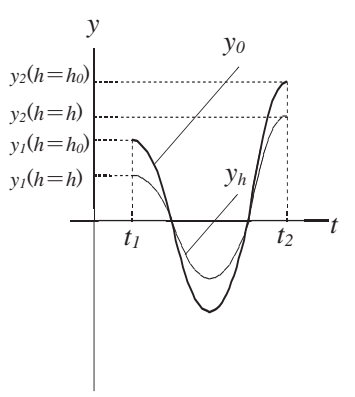

Fig.5 Assumption of the time history of the displacement

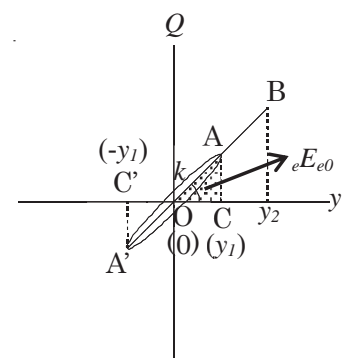

Fig.6 Strain energy and energy by damping force in one cycle $\left(A-A^{\prime}-A\right)$ 


\section{3. 応答低減係数の略算式とその検討課題}

応答低減係数の略算式は、減衰による吸収エネルギーの修正係数 $\beta_{0}\left((7)\right.$ 式)が突出比 $\gamma_{0}((6)$ 式 $)$ と等しいとし、(9)式で与えている6)。

$$
F_{h}=\frac{10 h_{0}+0.8\left(\gamma_{0}-1 / \gamma_{0}\right)}{10 h+0.8\left(\gamma_{0}-1 / \gamma_{0}\right)}
$$

しかしながら、上記の応答低減係数の略算式は応答低減係数を小 さめの值で評価しており、また、減衰定数 h が増加するにつれて応 答解析結果の平均值との差異が大きくなる傾向が見られた(後述 Fig.12 参照)。さらに、応答解析結果は減衰定数 h が同じであって も、建物周期 $\mathrm{T}$ によって応答低減係数の值が異なる結果となった。 したがって、応答低減係数の精度の向上を図るため、減衰定数 $\mathrm{h} か ゙$ 応答に及ぼす効果について更なる検討を行った。

\section{3. 応答低減係数の修正式の検討}

本章では、2.3 節の検討課題について 3.1 節に示す解析概要より 得られた応答解析結果を用いて検討を行う。 3.2 節では減衰による 吸収エネルギーの修正係数 $\beta_{0}$ を応答の非対称性を加味した係数と して新たに提示し、3.3 節では減衰定数 h による応答低減係数への

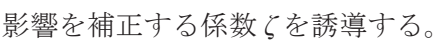

\section{1. 検討に用いた解析の概要}

解析対象モデルは弾性一質点系とし、建物周期 $\mathrm{T}$ を 0.5 秒 $~ 3.0$ 秒までの範囲で変化させ系の剛性を設定した。また、減衰定数 $\mathrm{h}$ は $0.05 、 0.1 、 0.15 、 0.2 、 0.25 、 0.3 、 0.35 、 0.4 の 8$ 種類とした。

入力地震動は告示波 3 種と実地震動 10 種の計 13 種類を対象とし た。Table 1 に告示波 3 波及び実地震動の最大加速度及び入力時間を 示す。告示波は模擬地震波作成プログラム $\mathrm{ARTEQ}^{7)}$ 用い、目標ス ペクトルを告示の 2 種地盤スペクトルとし、乱数を変化させ、 3 種 類の波形を作成した。Fig.7 に告示波 3 波の入力加速度波形を示す。 また、実地震動は様々な波が報告されているが、本論文では文献 8) の観測波(Tohoku、El Centro、Hachinohe、Taft)及び気象庁に公開 されている観測波(Kobe)を用い、それぞれの地震動の最大速度をレ ベル 2 に相当する $50 \mathrm{~cm} / \mathrm{s}$ に基準化した。なお、修正係数 $\beta_{0}$ の算出

Table1 Input earthquake motions

\begin{tabular}{|c|c|c|}
\hline Earthquake motion & Max acc. $\left(\mathrm{cm} / \mathrm{s}^{2}\right)$ & Time $(\mathrm{s})$ \\
\hline \hline Wave1 & 463.00 & 120.00 \\
\hline Wave2 & 443.00 & 120.00 \\
\hline Wave3 & 491.00 & 120.00 \\
\hline Tohoku NS & 356.63 & 40.96 \\
\hline Tohoku EW & 367.03 & 40.96 \\
\hline El Centro NS & 510.00 & 53.76 \\
\hline El Centro EW & 284.69 & 53.48 \\
\hline Hachinohe NS & 333.72 & 51.00 \\
\hline Hachinohe EW & 238.36 & 51.00 \\
\hline Taft NS & 486.31 & 54.38 \\
\hline Taft EW & 496.89 & 54.40 \\
\hline Kobe NS & 451.08 & 173.02 \\
\hline Kobe EW & 408.80 & 173.02 \\
\hline
\end{tabular}

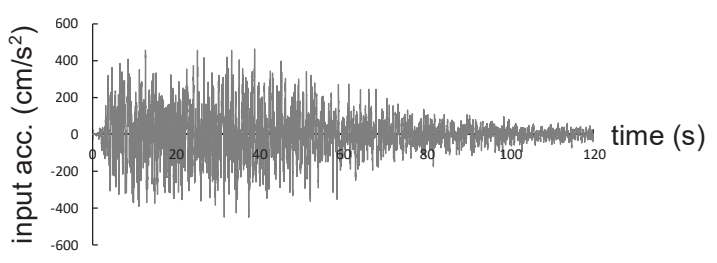

a) Wave1

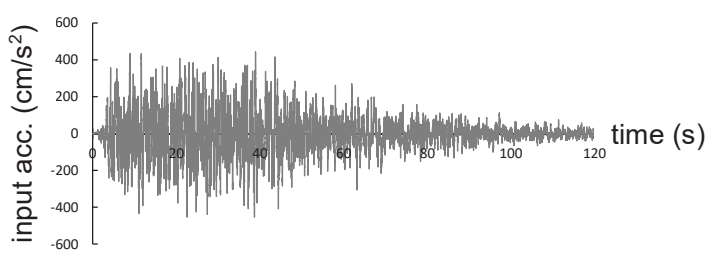

b) Wave2

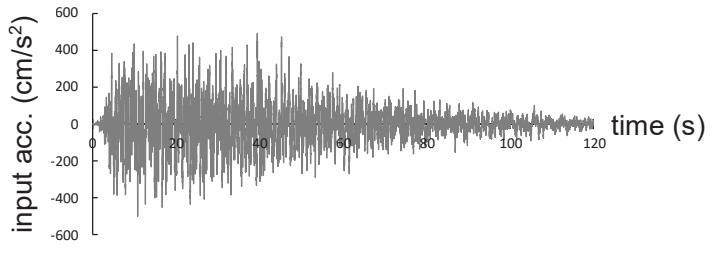

c) Wave3

Fig.7 Input earthquake motions in notification

には、減衰定数 $h=h_{0}$ の時における減衰による吸収エネルギーの正 確な值を把握する必要があるため、入力地震動の刻み時間を十分な 収束が見られた 0.002 秒とし、検討を行った。

\section{2. 応答の非対称性を加味した修正係数 $\beta_{0}{ }^{\prime}$ の検討}

一般的に等価減衰定数 $h$ は減衰による吸収エネルギー $\mathrm{e}_{\mathrm{d}} \mathrm{e}_{\mathrm{d}}$ と歪エ ネルギー $\mathrm{e}_{\mathrm{e}}$ を用いて $(10)$ 式で表される。

$$
h=\frac{1}{4 \pi} \cdot \frac{e^{E_{d}}}{{ }_{e} E_{e}}
$$

しかしながら、(10)式が成立するのは定常応答の場合であり実際 の応答のように正負非対称の応答を描く場合で(10)式のように表す には補正が必要になる。本論文ではこの補正を以下のように考えた。

Fig. 8 に正負非対称の応答を、Fig.9 に Fig. 8 の非対称の応答が対 称になるようにx 軸及び $\mathrm{y}$ 軸をずらした図を示す。ここで、Fig.9 に おける $\overline{y_{1}}$ は Fig.8 の $\mathrm{y}_{1}$ と $\mathrm{y}_{1}{ }^{\prime}$ の平均値を示す((11)式)。

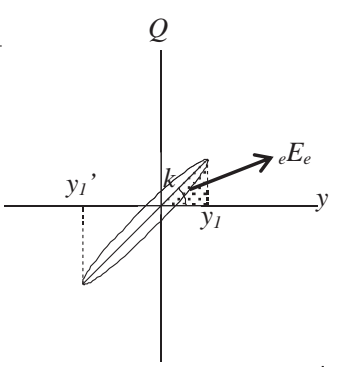

Fig.8 Displacement and strain energy in case of nonstationary response

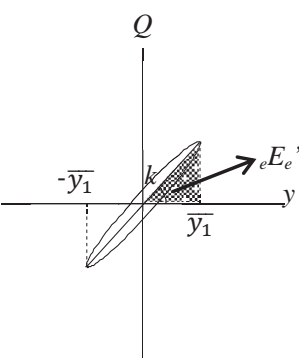

Fig.9 Modified displacement as to be stationary response and modified strain energy 


$$
\overline{y_{1}}=\frac{\left|y_{1}\right|+\left|y_{1}{ }^{\prime}\right|}{2}
$$

(10)式における歪エネルギー ${ }_{\mathrm{e}} \mathrm{E}_{\mathrm{e}}$ の代わりに Fig.9 の歪エネルギー ${ }_{\mathrm{e}} \mathrm{E}_{\mathrm{e}}{ }^{\prime}$ を用いれば、等価減衰定数と減衰による吸収エネルギー ${ }_{\mathrm{e}} \mathrm{E}_{\mathrm{d}}$ の間 に(12)式が成立する。結果として、非定常応答をする場合の等価減 衰定数 h’は(13)式で表される。

$$
\begin{gathered}
h^{\prime}=\frac{1}{4 \pi} \cdot \frac{e^{E_{d}}}{e^{E_{e}{ }^{\prime}}}=h \cdot \frac{e^{E_{e}}}{e^{E_{e}{ }^{\prime}}} \\
h^{\prime}=h \cdot\left(\frac{y_{1}}{\overline{y_{1}}}\right)^{2}
\end{gathered}
$$

なお、以下では文献 6)の提案式との継続性を保つため、等価減衰 定数は従来と同じとし、減衰定数 $h=h_{0}$ の時における減衰定数の補 正係数 $\left(y_{1} / \overline{y_{1}}\right)^{2}$ を修正係数 $\beta_{0}((7)$ 式 $)$ に乗じた応答の非対称性を加味 した減衰による吸収エネルギー $\mathrm{e}_{\mathrm{e} 0}$ の 修正係数 $\beta_{0}{ }^{\prime}$ を(14)式で表す。

$$
\beta_{0}^{\prime}=\beta_{0} \cdot\left(\frac{y_{1}}{\overline{y_{1}}}\right)^{2}
$$

Fig.10に、例として Wave1、Wave2、Tohoku NS、Hachinohe NS を用いた場合の減衰定数 $h_{0}$ が 0.05 及び 0.1 における、修正係数 $\beta_{0}\left((7)\right.$ 式)及び $\beta^{\prime}{ }_{0}\left((14)\right.$ 式)を示す。文献 $\left.{ }^{6}\right)$ の修正係数 $\beta_{0}$ は建物周期 $\mathrm{T}$ による差異が大きく、応答の非対称性を加味した修正係数 $\beta^{\prime}{ }_{0}$ は建 物周期 Tによる差異が概して小さい結果となった。

以上より、応答の非対称性による減衰定数への影響を加味した応 答低減係数(以下:応答低減係数の修正式)が(15)式で得られる。なお、 最大応答直前のピーク值である $\mathrm{y}_{1}$ が小さい場合、一律とした場合の 突出比 $\gamma_{0}((6)$ 式)の值に大きな影響を与え、結果として応答低減係数 も大きく変動することから、本論文では建物周期 T によらず応答低 減係数を表すため、(15)式の全ての項に突出比の逆数の 2 乗 $1 / \gamma_{0}{ }^{2}$ を 乗じた。なお、 $\gamma_{0}{ }^{2}$ で除すことは最大応答直前のピーク值ではなく最 大応答時の歪エネルギーを基準にして表すことを意味する。

$$
F_{h}=\frac{\beta_{0}{ }^{\prime} / \gamma_{0}^{2} \cdot 4 \pi h_{0}+\left(1-1 / \gamma_{0}^{2}\right)}{\beta_{0}{ }^{\prime} / \gamma_{0}^{2} \cdot 4 \pi h+\left(1-1 / \gamma_{0}^{2}\right)}
$$

Fig.11に、例として Wave1、Wave2、Tohoku NS、Hachinohe NS を用いた減衰定数 $h_{0}$ が 0.05 及び 0.1 の場合における、突出比の逆 数 $1 / \gamma_{0}$ を示す。突出比の逆数 $1 / \gamma_{0}$ は、建物周期 $\mathrm{T}$ によって值が異な るが、おおよそ一定の值を示しており、建物周期 Tによる影響度合 いはさほど大きくない。

Table 2 に各地震波から得られた減衰定数 $h_{0}$ が 0.05 及び 0.1 の場

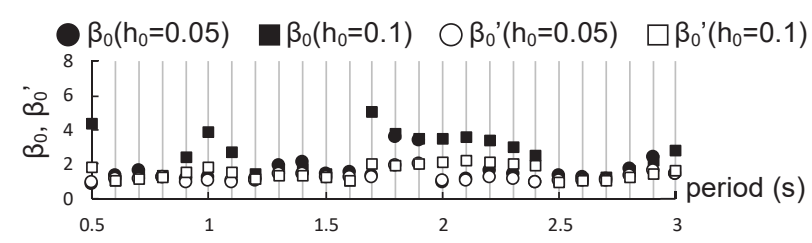

a) Wave 1

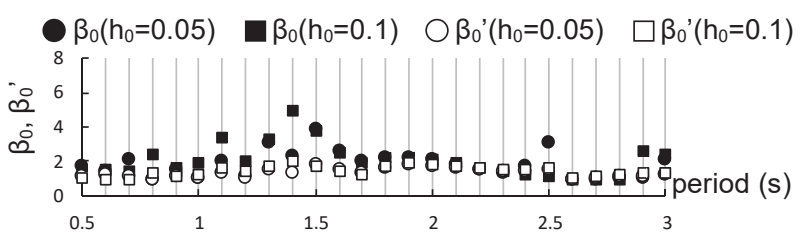

c) Tohoku NS

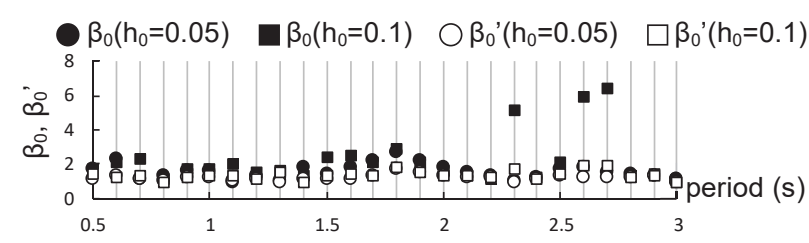

b) Wave2

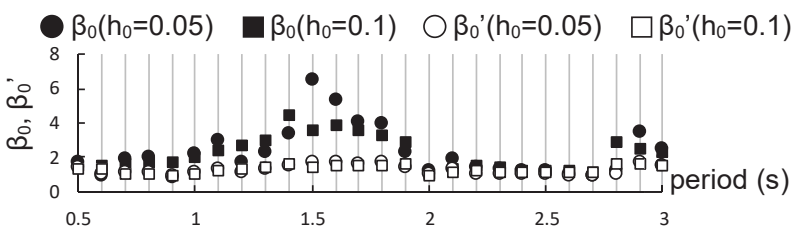

d) Hachinohe NS

Fig.10 The modified factor of absorbed energy by damping factor $\beta_{0}, \beta_{0}$ '
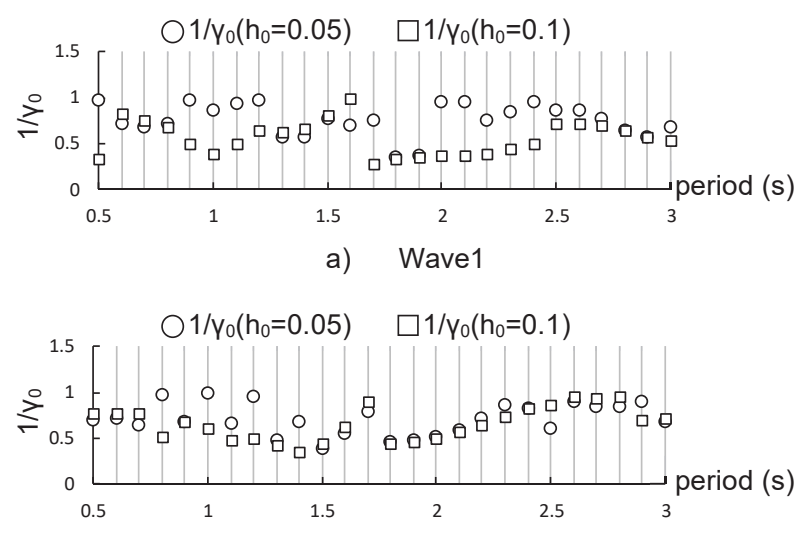

c) Tohoku NS

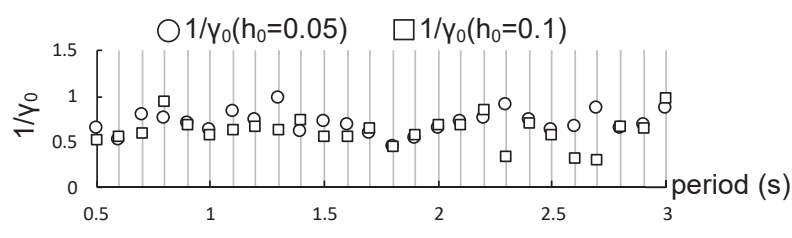

b) Wave2

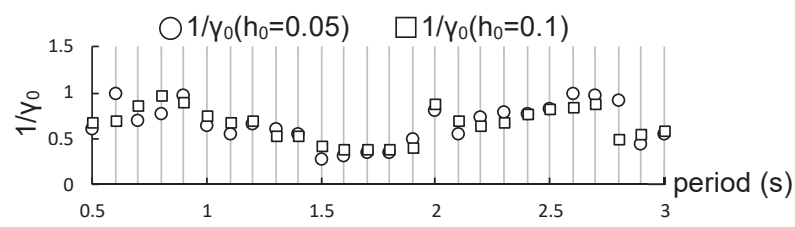

d) Hachinohe NS

Fig.11 The reciprocal of projected ratio at the maximum response $1 / \mathrm{y}_{0}$ 
Results of response analysis

$F_{h} \quad \square T=0.5 \quad \diamond T=1 \quad \Delta T=1.5 \quad \times T=2 \quad * T=2.5 \quad \circ T=3$

$1.6 *$ - Average of the analysis

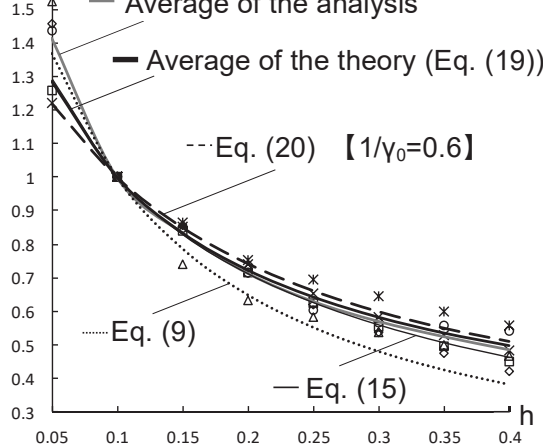

a) Wave1
Results of response analysis $\mathrm{F}_{\mathrm{h}} \quad \square \mathrm{T}=0.5 \quad \diamond \mathrm{T}=1 \quad \Delta \mathrm{T}=1.5 \quad \times \mathrm{T}=2 \quad \times \mathrm{T}=2.5 \quad \circ \mathrm{T}=3$ 1.6 娄 - Average of the analysis

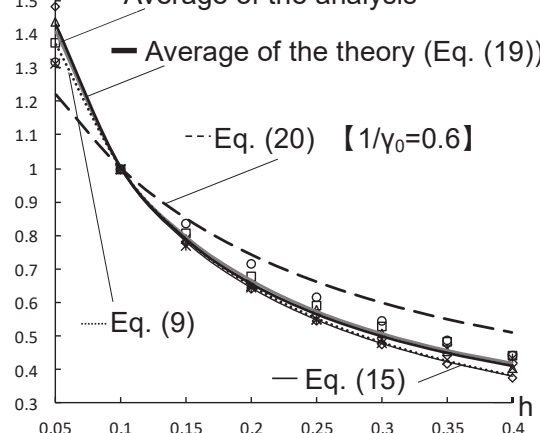

b) Wave2
Results of response analysis

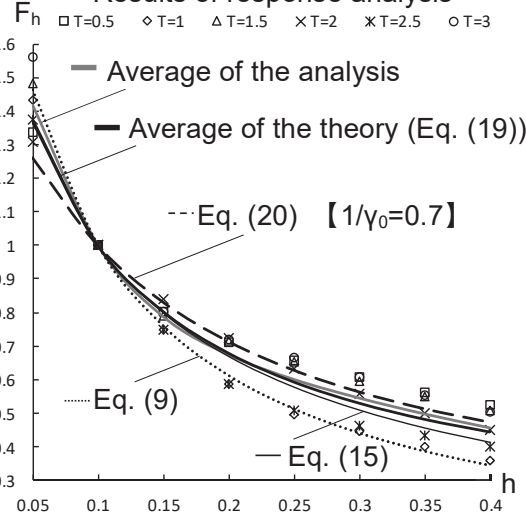

c) Wave3

Fig.12 Response reduction factor (Earthquake motions in notification)

合における $\beta_{0}{ }^{\prime} / \gamma_{0}^{2}$ と突出比の逆数 $1 / \gamma_{0}$ 及び減衰定数の補正係数 $\left(y_{1} / \overline{y_{1}}\right)^{2}$ の平均值を示寸。 $\beta_{0}{ }^{\prime} / \gamma_{0}{ }^{2}$ は最小值が 0.3 、最大值が 0.8 とな った。また、減衰定数の補正係数 $\left(y_{1} / \overline{y_{1}}\right)^{2}$ の值は減衰定数 $\mathrm{h}_{0}$ に係わ らず、おおよそ 0.7 となった。

Fig. 12 に、建物周期 T を 0.5、1.0、1.5、2.0、2.5、3.0 とし、告 示波 3 波を用いた場合の応答解析結果とその平均值、応答低減係数 の修正式((15)式)の平均值及び文献 6)で示した応答低減係数の略算 式((9)式)を示す。また、（15)式における修正係数 $\beta_{0}{ }^{\prime}$ と突出比の逆数 $1 / \gamma_{0}$ には前述のように建物周期 $\mathrm{T}$ ごとの值を用い、(9)式における突 出比 $\gamma_{0}$ には Table 2 の值を用いた。その他、減衰定数 $h_{0}$ は 0.1 とし た。なお、図中(19)式と (20)式の結果の検討については 3.3 節及び 4 章で後述する。Wave1 と Wave3 の場合、応答低減係数の略算式((9) 式)に対し応答低減係数の修正式((15)式)の方が応答解析結果の平均 值と良い対応を示した。Wave2 の場合では、応答低減係数の修正式 ((15)式) と応答低減係数の略算式((9)式)は殆ど同じであるが、もとも と応答低減係数の略算式 $((9)$ 式 $)$ の結果と応答解析結果の平均值との

Table2 The value of $\beta_{0}{ }^{\prime} / \mathrm{Y}_{0}{ }^{2}, 1 / \mathrm{Y}_{0},\left(\mathrm{y}_{1} / \overline{y_{1}}\right)^{2}$

\begin{tabular}{|c|c|c|c|c|c|c|}
\hline \multirow{2}{*}{ Earthquake motion } & \multicolumn{2}{|c|}{$\beta_{0}{ }^{\prime} / \gamma_{0}^{2}$} & \multicolumn{2}{c|}{$1 / \gamma_{0}$} & \multicolumn{2}{c|}{$\left(y_{1} / \overline{y_{1}}\right)^{2}$} \\
\cline { 2 - 7 } & $h_{0}$ & $h_{0}$ & $h_{0}$ & $h_{0}$ & $h_{0}$ & $h_{0}$ \\
& 0.05 & 0.1 & 0.05 & 0.1 & 0.05 & 0.1 \\
\hline \hline Wave1 & 0.7 & 0.5 & 0.8 & 0.6 & 0.8 & 0.7 \\
\hline Wave2 & 0.6 & 0.5 & 0.7 & 0.6 & 0.8 & 0.7 \\
\hline Wave 3 & 0.7 & 0.6 & 0.7 & 0.7 & 0.8 & 0.8 \\
\hline Tohoku NS & 0.7 & 0.6 & 0.7 & 0.7 & 0.8 & 0.8 \\
\hline Tohoku EW & 0.5 & 0.4 & 0.6 & 0.5 & 0.7 & 0.6 \\
\hline El Centro NS & 0.7 & 0.7 & 0.7 & 0.7 & 0.8 & 0.9 \\
\hline El Centro EW & 0.4 & 0.4 & 0.5 & 0.5 & 0.6 & 0.4 \\
\hline Hachinohe NS & 0.6 & 0.6 & 0.7 & 0.7 & 0.7 & 0.7 \\
\hline Hachinohe EW & 0.7 & 0.7 & 0.8 & 0.7 & 0.9 & 0.9 \\
\hline Taft NS & 0.6 & 0.7 & 0.7 & 0.7 & 0.7 & 0.7 \\
\hline Taft EW & 0.6 & 0.3 & 0.7 & 0.3 & 0.8 & 0.5 \\
\hline Kobe NS & 0.7 & 0.8 & 0.6 & 0.6 & 0.6 & 0.6 \\
\hline Kobe EW & 0.5 & 0.4 & 0.6 & 0.4 & 0.6 & 0.4 \\
\hline
\end{tabular}

差異が少ない。しかし、全ての告示波を用いた結果において、減衰 定数 $\mathrm{h}$ が大きい範囲で応答解析結果の平均值と応答低減係数の修正 式の平均值に差異が見られた。

\section{3. 減衰による周期への影響の考慮}

Fig.13、Fig.14 W Wave2 を用いた場合の 1 サイクル分の応答変 位 y と継続時間 $\mathrm{t}$ の関係を示す。なお、Fig.13 に建物周期 T を 0.5、 Fig.14 に建物周期 T を 1.0 とした結果を示寸。減衰定数 $\mathrm{h}$ の值によ って 1 サイクル分の応答周期が若干異なり、減衰定数 $\mathrm{h}$ の増大に伴 い概して応答周期が延びている。以下では、この減衰定数 $\mathrm{h}$ の増大 に伴う、応答周期の変動が応答低減係数に及ぼす影響を補正する係 数を提案する。

文献 9)より、減衰を有する一質点系が自由振動する場合、減衰定 数 $h$ の時の減衰応答周期 $T_{h}$ は、非減衰応答周期 $T$ を用いて (16)式で 与えられる。同様にして、減衰定数 $h_{0}$ の時の減衰応答周期 $T_{0}$ は、 (17)式となる。

$$
\begin{aligned}
& T_{h}=\frac{T}{\sqrt{1-h^{2}}} \\
& T_{0}=\frac{T}{\sqrt{1-h_{0}^{2}}}
\end{aligned}
$$

（16)式、(17)式より、減衰応答周期 $T_{0}$ と $T_{h}$ の時の応答の比は速

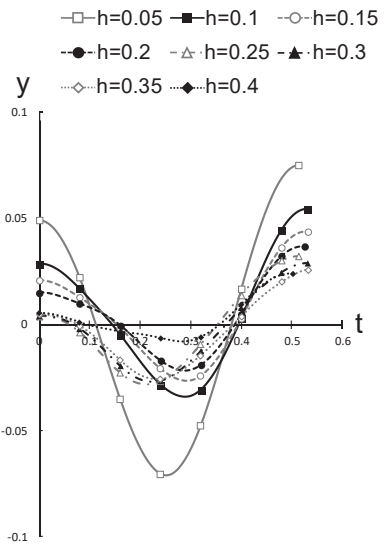

Fig.13 Time history of displacement $(\mathrm{T}=0.5)$

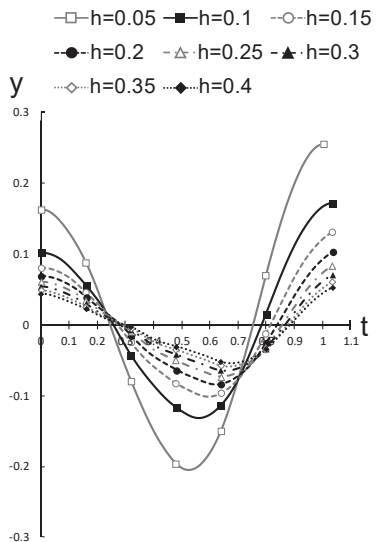

Fig.14 Time history of displacement $(T=1.0)$ 
度一定領域とすると $\mathrm{T}_{\mathrm{h}} / \mathrm{T}_{0}$ となる((18)式)。以下では、(18)式を減衰 定数 h の増大による応答低減係数への影響を補正する係数 $\zeta$ と、 その影響を検討した。

$$
\zeta=\frac{T_{h}}{T_{0}}=\sqrt{\frac{1-h_{0}^{2}}{1-h^{2}}} \doteqdot \sqrt{1+h^{2}-h_{0}^{2}}
$$

なお、定常応答時は減衰応答周期 $T_{h}$ と非減衰応答周期 $T$ が一致 し、減衰定数 h の増大による応答周期への影響がないことから補正 係数 $\zeta((18)$ 式)は 1 とする。

以上より、(15)式の応答低減係数の修正式を(19)式のように書き 換える。

$$
F_{h}=\frac{\beta_{0}{ }^{\prime} / \gamma_{0}^{2} \cdot 4 \pi h_{0}+\left(1-1 / \gamma_{0}^{2}\right)}{\beta_{0}{ }^{\prime} / \gamma_{0}^{2} \cdot 4 \pi h+\left(1-1 / \gamma_{0}^{2}\right)} \cdot \zeta
$$

前述 Fig.12 に、応答低減係数の修正式((19)式)の平均值と応答解 析結果の平均值の比較を示す。ここで、(15)式と同様に、(19)式にお ける修正係数 $\beta_{0}{ }^{\prime}$ と突出比の逆数 $1 / \gamma_{0}$ には建物周期 $T$ ごとの值を用

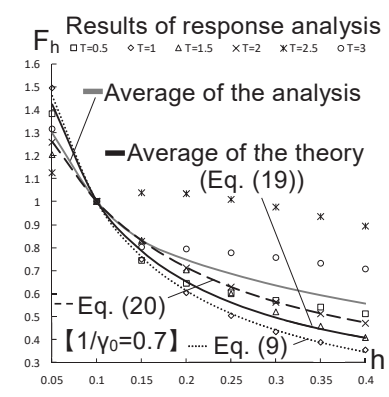

a) Tohoku NS

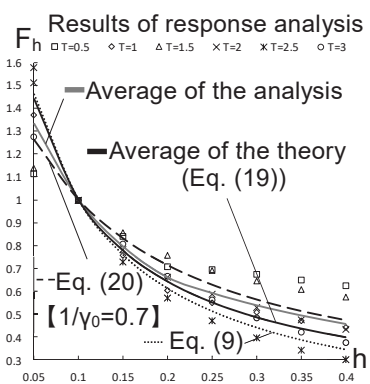

e) Hachinohe NS

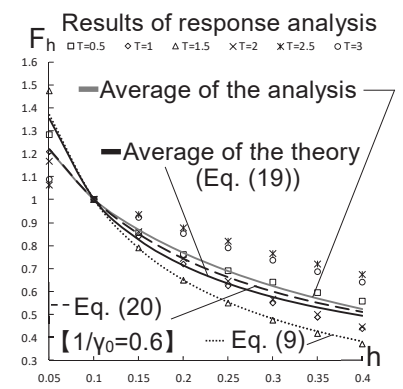

i) Kobe NS

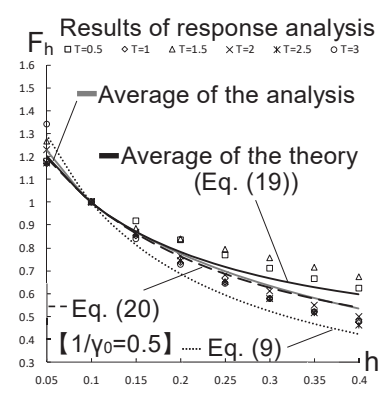

b) Tohoku EW

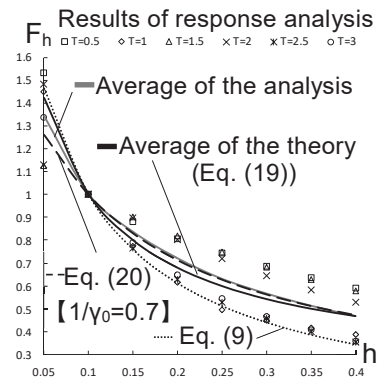

f) Hachinohe EW

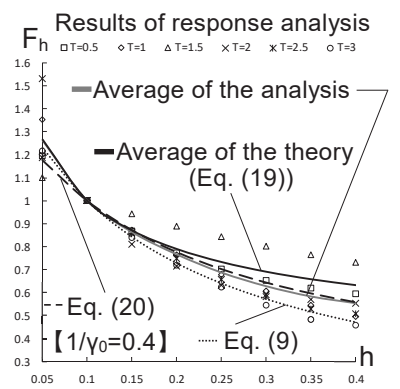

j) Kobe EW

Fig.15 Response reduction factor (Actual earthquake motions)
いた。その他、実地震動も検討対象であることから建物周期 T が 0.5 秒の場合も含めて $\zeta$ は $\mathrm{T}_{\mathrm{h}} / \mathrm{T}_{0}$ とした。なお、図中、(20)式及び実地震 動に対する結果の検討については 4 章で後述する。告示波を用いた

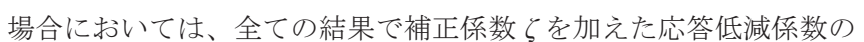
修正式((19)式)は応答解析結果の平均值とほとんど一致する結果と なった。

\section{4. 応答低減係数の簡易式の提案と解析結果及び既往式との比較}

本章では、応答低減係数の修正式((19)式)を基に、応答低減係数を 容易に評価しうる簡易式を提案し、応答解析結果及び既往の応答低 減係数の提案式と比較する。また、本論文で提案した応答低減係数 の修正式((19)式)と実地震動を用いた応答解析結果を比較し、その整 合性を検証する。

応答低減係数の簡易式は $(20)$ 式で与えられる。ここで、減衰によ る吸収エネルギーの過大評価を防ぐため、(19)式の $\beta_{0}{ }^{\prime} / \gamma_{0}{ }^{2} を$ Table 2 の最小值である 0.3 とし、応答低減係数の簡易式を導出した。なお、 (20)式における突出比の逆数 $1 / \gamma_{0}$ は Table 2 の值を用いる。

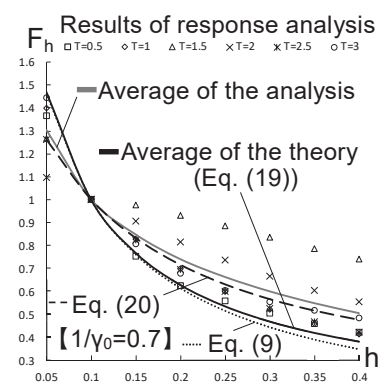

c) El Centro NS

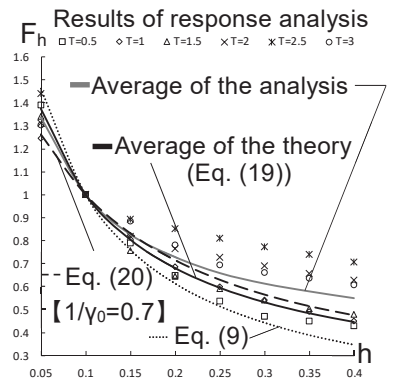

g) Taft NS

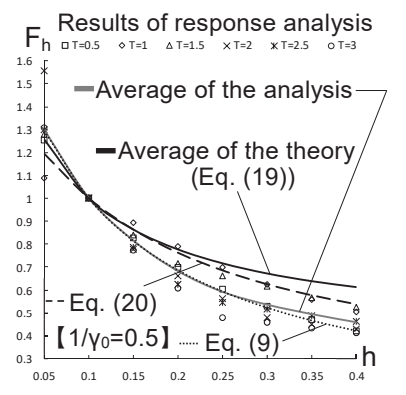

d) El Centro EW

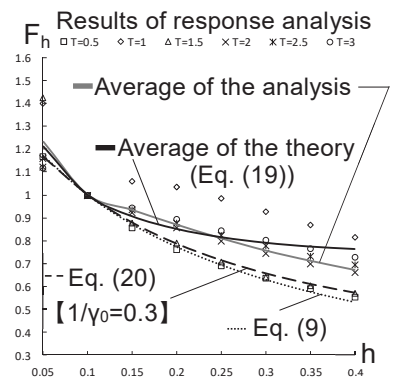

h) Taft EW

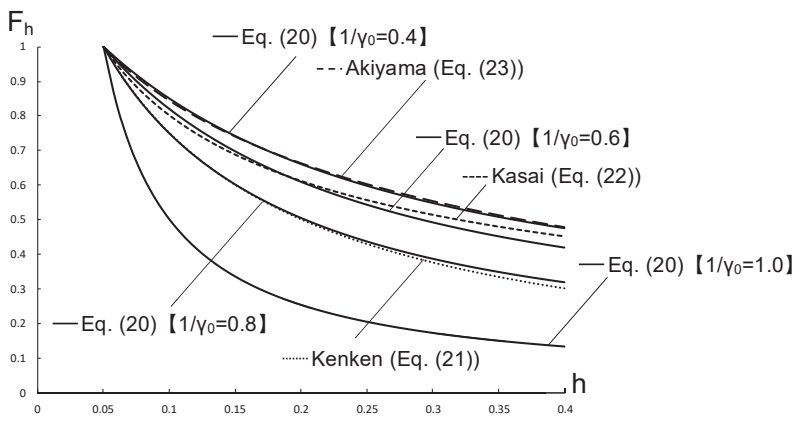

Fig.16 Comparison of proposals of response reduction factor 


$$
F_{h}=\frac{10 h_{0}+2.7\left(1-1 / \gamma_{0}^{2}\right)}{10 h+2.7\left(1-1 / \gamma_{0}^{2}\right)} \cdot \zeta
$$

前述 Fig.12に、告示波を用いた場合の応答解析結果の平均值と応 答低減係数の簡易式 $((20)$ 式 $)$ 比較を示す。応答低減係数の簡易式 ((20)式)は、Wave1 と Wave3 を用いた場合では応答解析結果の平均 值とほぼ一致する結果となり、Wave2 を用いた場合では応答解析結 果の平均值をやや過大評価する結果となった。

Fig.15 に実地震動を用いた場合の応答解析結果とその平均值、応 答低減係数の修正式((19)式)の平均値、応答低減係数の簡易式 $((20)$ 式)及び既往の応答低減係数の略算式((9)式)を示す。応答低減係数の 修正式((19)式)は、El Centro EW を除けば既往の応答低減係数の略 算式((9)式)と比較して応答解析結果の平均值と良い対応を示した。 また、Tohoku EW、Hachinohe NS、Hachinohe EW、Taft EW、 Kobe NS、Kobe EW の応答解析結果の平均值と良い整合性を示し、 Tohoku NS、El Centro NS、Taft NS では応答解析結果の平均值 を過小評価し、El Centro EW では応答解析結果の平均值を過大評 価した。応答低減係数の簡易式((20)式)も、El Centro EW を除けば 既往の応答低減係数の略算式 $((9)$ 式) と比較して応答解析結果の平均 值と良い対応を示した。また、Tohoku EW、El Centro NS、 Hachinohe NS、Hachinohe EW、Kobe NS、Kobe EW においては、 応答解析結果の平均值と良い整合性を示した。なお、Tohoku $\mathrm{NS}(\mathrm{T}=2.5) 、 \mathrm{El}$ Centro NS$(\mathrm{T}=1.5)$ 及び Taft EW(T=1.0)の応答解析結 果は他の建物周期 Tに比べ大きくばらつきが見られるが、これは主 として減衰定数 $h=0.1$ の時の最大応答変位 $\mathrm{y}_{2}$ が他の減衰定数 $h$ に 比べ小さ仕小さめの值となったためである。

Fig.16 に、代表的な既往の応答低減係数の提案式である建研式 ((21)式) 1)、笠井式((22)式) 2)、秋山式((23)式) 3)及び本論文で導出し た応答低減係数の簡易式((20)式)を示寸。なお、Fig.16 おける減衰定 数 hoは 0.05 とした。

$$
\begin{aligned}
& \text { 建研式 : } F_{h}=\frac{1+10 h_{0}}{1+10 h} \\
& \text { 笠井式 : } F_{h}=\sqrt{\frac{1+25 h_{0}}{1+25 h}} \\
& \text { 秋山式 : } F_{h}=\frac{1+3 h_{0}+1.2 \sqrt{h_{0}}}{1+3 h+1.2 \sqrt{h}}
\end{aligned}
$$

応答低減係数の簡易式((20)式)の突出比の逆数 $1 / \gamma_{0}$ を 0.8 とした 場合は建研式((21)式)、0.6 とした場合は笠井式((22)式)、0.4 とした 場合は秋山式((23)式)とほぼ一致する。また、建研式((21)式) と応答 解析結果の平均值の下限值が一致し、Taft EW を除けば秋山式((23) 式)と応答解析結果の平均值の上限值が一致した。建研式((21)式)は 主として告示波を、笠井式((22)式)、秋山式((23)式は実地震動を対象 として作成されていることが主たる理由であろう。

なお、実務的に応答低減係数の簡易式((20)式)を用いる場合、突出 比の逆数 $1 / \gamma_{0}$ については、長周期地震動で共振するような場合では 1.0 に近い值、告示波に対しては $0.6 \sim 0.8$ 程度の值をとることが考
えられる。また、直下地震のような地震動に対しては $0.3 \sim 0.5$ 程度 の值を実情に応じ判断して用いることが必要であろう。例えば、設 計者や行政判断の観点から安全側の設計を行う場合には、0.3もし くはそれ以下の值をとることなども考えられる。その他、Fig.15よ り、応答低減係数は建物周期 T の影響も見られるが減衰定数 $\mathrm{h}$ の方 が応答低減係数の第一次的な影響因子であり、減衰定数 $\mathrm{h}$ に比べれ ば建物周期 Tの影響が小さいこと、及び、弾塑性系の場合では建物 周期 T は応答周期を用いる必要があり、建物周期 T を応答低減係数 の関数とすると実務的に煩雑になることから、本論文では応答低減 係数の提案式を文献 ${ }^{6}$ と同様に建物周期 T の関数とせず、その平均 值に対しての適合性を検討した。

\section{5. まとめ}

本論文では、文献 ${ }^{6)}$ の非定常応答時の応答低減係数に応答の非対 称性を加味した減衰による吸収エネルギーの修正係数 $\beta_{0}{ }^{\prime}$ と、減衰定 数による周期の変動の影響を考慮した補正係数 応答低減係数の修正式を提案した。また、応答低減係数の修正式に 建物周期ごとの修正係数 $\beta_{0}{ }^{\prime}$ 及び突出比の逆数 $1 / \gamma_{0}$ を用い、具体的な 応答低減係数を算出した。さらに、提案した応答低減係数の修正式 を基に、応答低減係数の簡易式を提示した。

以下に、得られた知見を記す。

(1) 非定常応答時における応答低減係数を評価するための減衰定 数の補正係数は $\left(y_{1} / \overline{y_{1}}\right)^{2}$ となる。ここで、 $\mathrm{y}_{1}$ は最大応答直前の ピーク值、 $\overline{y_{1}}$ は最大応答直前のピーク值と負側の最大変位の 平均值である。また、本例ではその平均值はおおよそ 0.7 とな った。

(2) 非対称の応答による減衰による吸収エネルギーへの影響を加 味した修正係数 $\beta_{0}{ }^{\prime}$ を減衰定数の補正係数 $\left(y_{1} / \overline{y_{1}}\right)^{2}$ と減衰によ る吸収エネルギーを表す $\beta_{0}$ より誘導し、 $\beta_{0}{ }^{\prime}$ は建物周期の影響 が小さいことを示した。

(3) 減衰定数による周期の変動を考慮した補正係数 らを誘導し、 応答低減係数の修正式を提案した。

(4) 非定常応答時の応答低減係数の修正式は下式で与えられる。

$$
F_{h}=\frac{\beta_{0}{ }^{\prime} / \gamma_{0}^{2} \cdot 4 \pi h_{0}+\left(1-1 / \gamma_{0}^{2}\right)}{\beta_{0}{ }^{\prime} / \gamma_{0}^{2} \cdot 4 \pi h+\left(1-1 / \gamma_{0}^{2}\right)} \cdot \zeta
$$

ここで、 $\beta_{0}^{\prime}$ は応答の非対称性を加味した減衰による吸収エネ ルギーの修正係数、 $\gamma_{0}$ は突出比、らは減衰による周期の変動を 補正する係数、 $h$ 及び $h_{0}(=10 \%)$ は減衰定数である。

(5)応答低減係数の修正式に、建物周期ごとの修正係数 $\beta_{0}{ }^{\prime}$ と突出 比の逆数 $1 / \gamma_{0}$ を用いた平均值が、告示波による応答解析結果 の平均值とほぼ一致することを示した。また、実地震動に対し ても文献 6 (の応答低減係数の略算式より良い対応を示す。

(6) 応答低減係数の修正式の $\beta_{0}{ }^{\prime} / \gamma_{0}{ }^{2}$ を安全側の 0.3 とし、応答低減 係数の簡易式を下式とした。

$$
F_{h}=\frac{10 h_{0}+2.7\left(1-1 / \gamma_{0}^{2}\right)}{10 h+2.7\left(1-1 / \gamma_{0}^{2}\right)} \cdot \zeta
$$

応答低減係数の簡易式は文献 $\left.{ }^{6}\right)$ の忘答低減係数の略算式より 応答解析結果の平均值と良い対応を示す。なお、突出比の逆数 $1 / \gamma_{0}$ を 0.8 とした場合は建研式、0.6 とした場合は笠井式、 0.4 とした場合は秋山式とほぼ一致する。 
本研究では、気象庁に公開されている強震波形(1995 年兵庫県南 部地震)を利用させていただきました。ここに記し、深く感謝の意を

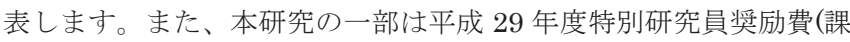

題番号：17J02633、研究代表者 : 大塚悠里)により行った。

\section{参考文献}

1) Commentary on Structural Regulations of the Building Standard Law of Japan Editorial Committee: 2015nenban Kenchikubutsu no Kouzoukankei Gijutsukijun Kaisetsusho (Commentary on Structural Regulations of the Building Standard Law of Japan 2015 Edition), Official Gazette Cooperation of Japan, 2015(in Japanese) 建築物の構造関係技術基準解説書編集委員会 : 2015 年版建築物の構 造関係技術基準解説書,全国官報販売協同組合, 2015

2) Kasai, K., Ito, H. and Watanabe, A. : Peak Response Prediction Rule for a Sdof Elasto-Plastic System Based on Equivalent Linearization Technique, Journal of Structural and Construction Engineering (Transactions of AIJ), No.571, pp.53-62, 2003.9(in Japanese)

笠井和彦，伊藤浩資，渡辺厚 : 等価線形化手法による一質点弾塑性構 造の最大応答予測法，日本建築学会構造系論文集，第 571 号, pp.53$62,2003.9$

3) Akiyama, H. : Earthquake-Resistant Design Method for Buildings Based on Energy Balance, Gihodo Shuppan Co., Ltd. 1999(in Japanese)

秋山宏：エネルギーの釣合に基づく建築物の耐震設計，技報堂出版， 1999

4) Okano, H., Nagano, M., Imamura, A., Tokumitsu, R. and Hijikata, K. : Scaling Equation Between Response Spectrum and Energy Spectrum, Journal of Structural and Construction Engineering (Transactions of AIJ), Vol.74, No.637, pp.477-486, 2009.3 (in Japanese)

岡野創, 永野正行, 今村晃, 徳光亮一, 土方勝一郎 : 応答スペクトル とエネルギースペクトルのスケーリング，日本建築学会構造系論文 集, 第 74 巻, 第 637 号, pp.477-486, 2009.3

5) Hiraishi, H., Otsuka, Y., Zhu, Y., Oi, K., Ode, D. and Kobayashi, M. : Study on Response Evaluation of Buildings at Resonance, Journal of Structural and Construction Engineering (Transactions of AIJ), Vol.81, No.719, pp.19-27, 2016.1(in Japanese)

平石久廣, 大塚悠里, 朱盈, 大井希良里, 大出大輔, 小林正人：建築 物の共振時における応答評価に関する研究, 日本建築学会構造系論 文集，第 81 巻，第 719 号, pp.19-27, 2016.1

6) Hiraishi, H., Zhu, Y., Oi, K., Otsuka, Y., Ode, D. and Inai, E. : The Evaluation of Reduction Factor by Damping in Non-Stationary Elastic Response Based on Energy Theory, Journal of Structural and Construction Engineering (Transactions of AIJ), Vol.81, No.719, pp.29-37, 2016.1(in Japanese) 平石久廣, 朱盈, 大井希良里, 大塚悠里, 大出大輔, 稲井栄一：エネ ルギーに立脚した非定常弾性応答における減衰による応答低減係数 の評価, 日本建築学会構造系論文集, 第 81 巻, 第 719 号, pp.29-37, 2016.1

7) Kozo Keikaku Engineering Inc. : ARTEQ for Windows Version6.1

8) Matsushima, Y., Research Leader : Kousoukenchikubutsu no Doutekikaisekiyou Jishindou ni Kansurukenkyuu (Study on Seismic Motions for Dynamic Analysis of High-Rise Buildings), 1994 BCJ Research Grant Report, No.9404, 1995(in Japanese) 研究代表者 松島豊 : 高層建築物の動的解析用地震動に関する研 究, (財) 日本建築センター平成 6 年度研究助成報告書 No.9404, 1995

9) Shibata, A. : Dynamic Analysis of Earthquake Resistant Structures, Tohoku Univ. Press, 2010 


\title{
Yuri OTSUKA ${ }^{* 1}$, Ying $Z \mathrm{HU}^{* 2}$, Miei ITO ${ }^{* 3}$,
} Daisuke ODE ${ }^{* 4}$ and Hisahiro HIRAISHI ${ }^{* 5}$

\author{
${ }^{* 1}$ Grad. Student, Graduate School of Science and Technology, Meiji Univ. \\ Research Fellow of Japan Society for the Promotion of Science, M.Eng. \\ *2 Technology Development Division, Fujita Corporation, M.Eng. \\ ${ }^{* 3}$ Grad. Student, Graduate School of Science and Technology, Meiji Univ. \\ ${ }^{*}$ Technical Research Institute, Obayashi Corporation \\ Grad. Student, Graduate School of Science and Technology, Meiji Univ., M.Eng \\ ${ }^{* 5}$ Prof., Dept. of Architecture, School of Science and Technology, Meiji Univ., Dr.Eng.
} (Visiting Research Fellow, Building Research Institute)

This paper presented an accurate response reduction factor for non-stationary elastic response which was modified from the past reduction factor in Ref.6). In the modification, the influence of the asymmetry of the response of the absorbed energy by the damping factor of one cycle just before the maximum response was taken into account, and the influence of the damping factor on the building period was also taken into account.

Furthermore, the paper proposed the simplified formula for response reduction factor

Finally, the compatibility was examined for both the modified formula and the simplified formula using the response analytical results by actual earthquake motions and earthquake motions in notification.

The major findings obtained in this paper were as follows.

1) The correction coefficient of the equivalent damping factor for evaluating the response reduction factor in non-stationary response is $(y 1 / y 1-2$. Here, $y 1$ is the peak value before the maximum response, and $y 1$-is the average of $y 1$ and the opposite peak value before the maximum response. The average value of $(\mathrm{y} 1 / \mathrm{y} 1-1) 2$ is approximately 0.7 .

2) It is proved that the new modified factor $\beta 0^{\prime}$ of the absorbed energy by damping factor which taken the influence the asymmetry of the response into account is less influenced by the period of the buildings than the modified factor $\beta 0$ of absorbed energy by damping factor proposed in Ref.6).

3) The modified formula for response reduction factor in non-stationary elastic response is expressed as $\mathrm{Fh}=\left[\left\{\beta 0^{\prime} / \gamma 0^{\prime} 2 \cdot 4 \pi \mathrm{h} 0+(1\right.\right.$ $\left.\left.\left.-1 / \gamma 0^{\prime} 2\right)\right\} /\left\{\beta 0^{\prime} / \gamma 02 \cdot 4 \pi h+(1-1 / \gamma 02)\right\}\right] \cdot \zeta$. Here, $\gamma 0$ is the projected ratio at the maximum response, and $\mathrm{h} 0(=10 \%)$ and $\mathrm{h}$ are damping factors.

4) The modified formula for response reduction factor using $\beta 0^{\prime} / \gamma 02$ and $1 / \gamma 0$ for each building period shows better compatibility with the response analytical results using actual earthquake motions and earthquake motions in notification than the past approximate formula of response reduction factor of Ref.6) does.

5) The simplified response reduction factor can be expressed as $\mathrm{Fh}=[\{10 \mathrm{~h} 0+2.7(1-1 / \gamma 02)\} /\{10 \mathrm{~h}+2.7(1-1 / \gamma 02)\}] \cdot \zeta$ in which $\beta 0^{\prime} / \gamma 0^{\prime} 2$ is set to be 0.3 considering safety side. The simplified formula shows excellent correlation with the results of the response analysis than the past approximation formula dose. When $1 / \gamma 0$ is set to 0.4 , it is close to Akiyama Formula, and when it is set to 0.6 , it is close to Kasai formula, and when it is set to 0.8 , it is close to Kenken formula. 